\title{
"DOTKNĘŁA FRĘDZLI JEGO PŁASZCZA" (ŁK 8, 44) - INTERPRETACJA ZDANIA W ŚWIETLE STAROŻYTNYCH ŚWIADECTW BIBLIJNYCH I POZABIBLIJNYCH
}

Obecna w potrójnej tradycji synoptycznej perykopa o kobiecie cierpiącej na krwotok (Mk 5, 24b-34; Mt 9, 20-22; Łk 8, 42b-48) wyróżnia się spośród innych opisów uzdrowień niespotykanymi gdzie indziej szczegółami. Tekst, zwłaszcza w redakcji Marka, ale też Łukasza, skonstruowany jest w taki sposób, by ukazać, iż uzdrowienie kobiety dokonuje się niejako automatycznie na skutek dotknięcia (i wiary) kobiety, a bez aktualnego działania Jezusa (Mk 5, 29-30; Łk 8, 44.46). Jezus zdaje się nie wiedzieć, kto został uzdrowiony, a jedynie, że „moc wyszła od Niego” (por. Mk 5, 30 ; Łk 8, 46). Co szczególnego było w chorej kobiecie, w jej dotyku, że spowodowa-

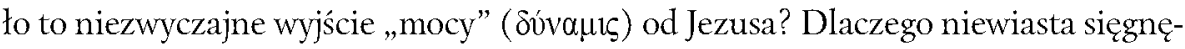
ła konkretnie po frędzle Jezusowego płaszcza, jak podają Mateusz i Łukasz, a Marek pomija ten szczegół? Czy wiedziała, że jest nieczysta według żydowskiego prawa, i sądziła, że nie wolno jej nikogo dotykać? A może zwyczajnie rozumiała, że nie wypada dotykać nieznanego mężczyzny, i sięgnęła po najdalszą część szat Jezusa, ponieważ miała nadzieję, iż w ten sposób jej działanie pozostanie ukryte? Mogła téz przywiązywać jakąś szczególną wagę do tej ozdoby i zakładała, że może zostać uzdrowiona właśnie przez dotknięcie tej, a nie innej części ubioru. Czy żydowskie frędzle u płaszcza miały w czasach Jezusa szczególne znaczenie, tak iż sądzono, że ich dotyk może uzdrawiać? Zaczynając poszukiwania, które mają udzielić odpowiedzi na powyższe pytania, zwrócimy uwagę na kontekst perykopy i charakterystykę kobiety (1). Następnie zatrzymamy się na wyrażeniu, które polskie tłumaczenia oddaja

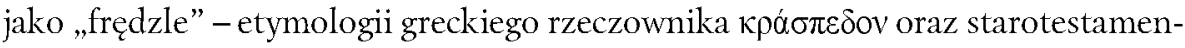
towych hebrajskich określeniach tej ozdoby (2). Na tej podstawie przeanalizujemy żydowską interpretację nakazu noszenia frędzli (3). Dalej spojrzymy na świadectwa 
ich noszenia w starożytnych kulturach - zarówno przedstawienia w formie obrazów (malowidła, płaskorzeźby, figury itp.), jak i pisane. Zachowane teksty ukażą nam znaczenie, jakie miały frędzle w starożytności (4). Na bazie takiej analizy będziemy mogli wyciągnąc wnioski (5), które w pewnej mierze będą odpowiedzią na postawione pytania, w innej zaś otworzą nowe obszary dla dalszych badań.

\section{SYNOPTYCZNE OPISY UZDROWIENIA KOBIETY CIERPIĄCEJ NA KRWOTOK}

\subsection{Kontekst literacki opisów}

W trzech relacjach synoptycznych perykopa znajduje miejsce w części ukazującej Jezusa jako uzdrowiciela-cudotwórcę przygotowującego uczniów do zadania głoszenia Dobrej Nowiny. Historia uzdrowienia kobiety cierpiącej na krwotok jest według synoptyków nierozdzielnie złączona z opisem wskrzeszenia córki Jaira, tworząc z nią jedną perykopę o tzw. strukturze sandwich - A1 B A2 $2^{1}$. Części A1 i A2 dotyczą córki Jaira, a centralna część B to historia kobiety cierpiącej na krwotok - punkt wyjścia dla naszej pracy. Dla obu uzdrowień można wskazać sporo wspólnych motywów: lęk, wiara, dotyk, córka, prostracja, nieczystość rytualna, beznadziejność sytuacji, liczba dwanaście ${ }^{2}$. Uzdrowienie córki przełożonego synagogi jest ewidentnie powiązane z opisem uzdrowienia kobiety, jednak pozostaje poza ramami niniejszego tekstu ${ }^{3}$.

\subsection{Charakterystyka chorej kobiety}

Do Jezusa zbliża się chora niewiasta. Wydaje się, że ma dwa pragnienia: zostać niezauważona i uzdrowiona. Pierwsze z nich często tłumaczone jest twierdzeniem, że kobieta, będąc rytualnie nieczysta, poprzez dotknięcie drugiej osoby przekracza prawo zawarte w Kpł 15, 25-27. Rzeczywiście, zasady czystości określone przez Torę

1 Por. J.R EDwaRds, The Gospel According to Mark (The pillar New Testament commentary), Grand Rapids, MI 2002, s. 160-161.

2 Por. A. KuBiś, Kobieta cierpiąca na krwotok oraz córka Jaira jako symbol Izraela. Próba analizy symbolicznej Mk 5, 21-43, w: Studia nad Ewangelia wedlug św. Marka. Nowy Testament: geneza-interpretacja - aktualizacja (Lingua Sacra. Monografie 8), red. W. Linke, J. Kręcidło, Warszawa-Ząbki 2017, s. 66; M. Moj, Kompozycje warstwowe w Ewangelii Marka (Attende Lectioni. Series Nova 1), Tarnów 2018, s. 107, 111, 138.

3 Uwagą do odnotowania, dotyczącą części A perykopy, jest sugestia pochodząca od Efrema Syryjczyka, który stwierdza, że wiara kobiety zaistniała dopiero w momencie, kiedy Jezus zgodził się udać do domu Jaira, by uratować jego córkę. Niewiasta uwierzyła, że Mistrz z Nazaretu może uratować dziewczynkę bliską śmierci, i to zrodziło w niej wiare, że i ją jest w stanie uzdrowić. Por. EFREm SyryJCZyk, Saint Ephrem's Commentary on Tatian's Diatessaron: An English Translation of Chester Beatty Syriac MS 709 (Journal of Semitic Studies, suppl. 2), red. C. McCarthy, Oxford 1993, 7, 26; A. Just, T.C. Oden, Luke (Ancient Christian Commentary on Scripture. New Testament 3), Downers Grove, IL 2003, s. 143. 
dotyczące pozamenstruacyjnego krwawienia ginekologicznego czyniły kobietę nieczystą rytualnie (podobnie jak jakikolwiek „wyciek” u mężczyzny - por. Kpł 15, 1-33). Taki przedłużający się stan mógł skutkować rozwodem lub niemożnością zamążpójścia. Pociągał zatem za sobą ekonomiczne konsekwencje ${ }^{4}$. $Z$ powodów pozanormatywnych, naturalnych, w oczywisty sposób oznaczało to niepłodność. Jednak nie wydaje się zasadna teoria, że poprzez swoją chorobę kobieta doświadcza dwunastoletniego wykluczenia ze społeczności, w której żyje. Faktycznie jest nieczysta religijnie (zakaz wchodzenia na teren świątyni, uczestniczenia w kulcie) oraz seksualnie (zabronione współżycie - czyli odsunięcie od przestrzegania pierwszego Bożego przykazania: „Bądźcie płodni i rozmnażajcie się, abyście zaludnili ziemię”, Rdz $1,28)^{5}$. Natomiast nie ma zapisu w ST ani innych pozabiblijnych dowodów na istnienie zakazu dotykania drugiej osoby bądź uczestniczenia w zwykłym życiú. Jezus przez fakt dotknięcia Go przez nieczystą kobietę nie traci czystości rytualnej (traci ją natomiast przez dotknięcie zwłok córki Jaira - por. Lb 19, 11-16).

Drugie pragnienie kobiety wynika z ciężaru jej choroby. Powagę dolegliwości odczytujemy z informacji o bezskutecznych i drogich próbach leczenia przez lekarzy (por. Mk 5, 25n.; Łk 8, 43). Z Talmudu możemy zaczerpnąć informacje o sposobach leczenia tego rodzaju schorzeń ${ }^{7}$. W prawdzie jest dyskutowane, czy upływ krwi, o którym piszą synoptycy, oznacza rzeczywiście chorobę ginekologiczną, jednak z pewnością niewiasta doświadcza uciążliwej przypadłości ${ }^{8}$. Kobieta na pewno

4 Społeczny status niezamężnej kobiety nie pozwalał jej na zarządzanie majątkiem czy dziedziczenie; por. À. PACIOREK, Ewangelia wedlug świętego Mateusza, rozdzialy 1-13. Wstęp, przekład z oryginatu, komentarz (NKBNT 1), Częstochowa 2005, s. 415.

5 Krwawienie menstruacyjne powodowało nieczystość sakralną także w innych kulturach (m.in. u Greków czy Polinezyjczyków). Wśród Żydów niektóre grupy (np. saduceusze) odrzucały ścisłe przestrzeganie przepisów w tej kwestii. Por. C.S. KeENER, A Commentary on the Gospel of Matthew, Cambridge 1999, s. 310, przypis 97.

6 Por. B. StRzAtKowska, Rozporządzenia dotyczace kobiet w Kpt 15 (Rozprawy i studia biblijne 20), Warszawa 2006, s. 97. Wyczerpująco tę kwestię omawia A. Kubiś, Kobieta cierpiąca na krwotok oraz córka Jaira jako symbol Izraela, s. 86-94. Do zebranych argumentów można dodać jeszcze jeden: statystycznie kilka razy do roku kobietom mieszkającym razem menstruacja wypada w tym samym czasie. Norma wyłączająca miesiączkujące kobiety z życia domowego (w tym zabraniająca dotyku) byłaby nie do przyjęcia dla mężczyzn (stanowiących prawa), gdyż czasem na parę dni musieliby sami przejąć wszystkie obowiązki domowe.

7 Por. W.L. Lane, The Gospel of Mark (NICNT), Grand Rapids, MI 1974, s. 192; H.L. STRACK, P. Billerbeck, Kommentar zum Neuen Testament aus Talmud und Midrash, Monachium 1954, s. 520. Metodą leczenia było np. wypicie czary wina zmieszanego z proszkiem z szafranu i żywicy (por. b.Szab. 110a).

8 Niek tórzy kwestionują teorię, że perykopa odnosi sie do choroby ginekologicznej i czystości rytualnej kobiet w ówczesnym Izraelu. Istnieje jednak słowne podobieństwo wyrażeń użytych w opi-

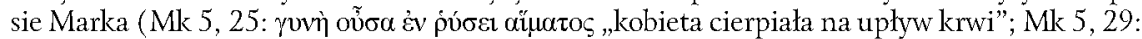

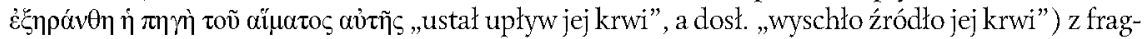

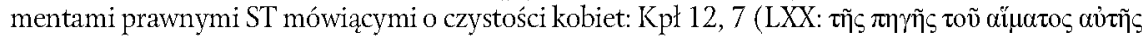

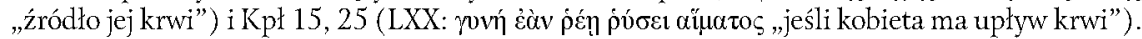
$Z$ tego powodu wydaje się zasadne przyjęcie, że passus odnosi się do tego tematu, a kobieta cierpi 
należała do zamożniejszych warstw społeczeństwa, gdyż tylko bogatych stać było na kuracje u lekarzy. Trudny stan niewiasty został podkreślony w Ewangelii Markowej również na poziomie tekstu, poprzez grę słów. W pierwszej części (Mk 5, 25b-26a) Marek notuje, że kobieta wiele wycierpiała ( $\pi 0 \lambda \lambda \dot{\alpha} \pi \alpha \theta 0 \tilde{\sigma} \sigma \alpha)$ od wielu lekarzy (

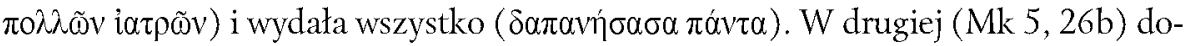

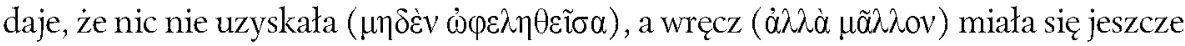
gorzej $(\chi \varepsilon \bar{\varphi} \text { pov } \dot{\varepsilon} \lambda \theta 0 \tilde{\sigma} \sigma \alpha)^{9}$. Także w warstwie symbolicznej można zauważyć powagę stanu kobiety, wskazując na semickie rozumienie krwi jako siedliska fizycznej funkcji życia. Niewiasta traci krew - symbol życia ${ }^{10}$. Z całą pewnością jest doświadczona przez ciężką chorobę i jak dotąd bezskutecznie szuka pomocy.

Ewangeliści nie mówią nic więcej o naszej bohaterce. Czy była wierzącą Żydówką, czy poganką? Czy jej wiara w moc Jezusa była powierzchowna i oparta na przesądach, czy też nie? Tego nie wiemy ${ }^{11}$. Tekst Mk 5, 28 (por. Mt 9,21) jest jednak skomponowany w taki sposób, że może sugerować, iż wiara niewiasty podszyta była myśleniem magicznym. Poprzez dotknięcie szaty Jezusa uzdrowienie miało się dokonać samoistnie. I rzeczywiście, nietypowe sformułowanie: „moc wyszła od Niego” (Mk 5,30 ), które pojawia się tylko tu (także w paralelnym miejscu u Łk 8,46) oraz w Łk 6, 19 (ttum stara się dotknąć Jezusa, bo moc wychodzi od Niego i uzdrawia wszystkich), mogłoby potwierdzać takie rozumienie fragmentu ${ }^{12}$. Nie każde dotknięcie Mistrza z Nazaretu skutkowało uzdrowieniem. Zwraca uwagę różnica między do-

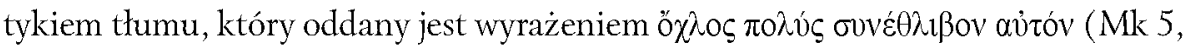

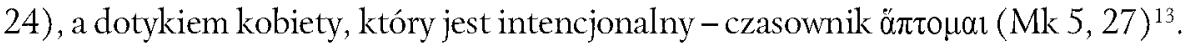
Jedynie u Mateusza kobieta zostaje uzdrowiona nie przez sam dotyk, ale dopiero na słowa Jezusa: „Ufaj, córko! Twoja wiara cię ocaliła” (Mt 9, 22b). Być może Mateusz $\mathrm{w}$ ten sposób ominą dostrzeżoną niezręczną sugestię, że dotknięcie płaszcza Jezusa mogło magicznie uzdrawiać ${ }^{14}$.

na pozamenstruacyjny upływ krwi. Por. S. MiLleR, Women in Mark's Gospel, London-New York, NY 2004, s. 52-53.

9 Por. J.R. EDwards, The Gospel According to Mark, s. 163; R. Gundry, Mark, Grand Rapids, MI 2000 , s. 269.

10 Więcej zob. P. Nyк, Obraz człowieka w Biblii. Elementy antropologii biblijnej, „Itinera Spiritualia” $10 / 1(2017)$, s. $153-154$.

11 Według greckiej tradycji niewiasta, która zbliża się do Jezusa, ma na imię Berenike. Akta Piłata (VII, 1) z IV wieku mówią o Weronice, tak też podają tradycje koptyjska i łacińska. Euzebiusz z Cezarei stwierdza, że była Żydówką, a pochodziła z Cezarei Filipowej (Historia kościelna VII, 18, 1). Późniejsze podanie utożsamiało ją z Weroniką ocierającą twarz Chrystusowi z szóstej stacji nabożeństwa drogi krzyżowej. Por. W.L. Lane, The Gospel of Mark, s. 194.

12 Owa „moc” powinna być interpretowana w kluczu „mocy Bożej” występującej w Piśmie Świętym. Jezus posiada moc Boga, gdyż jest Jego reprezentantem na ziemi. Por. tamże, s. 192.

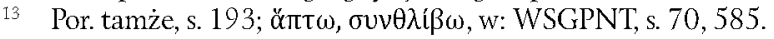

14 Por. R.T. France, The Gospel of Matthew (NICNT), Grand Rapids, MI 2007, s. 363. Przeciw takiemu odczytaniu tego fragmentu jest D.J. HaRrington, The Gospel of Matthew (Sacra Pagina 1), Collegville, MI 1991, s. 131. Jezus podkreśla także, w każdej z wersji, że to wiara uzdrowiła 
$\mathrm{Na}$ czym zatem mogła polegać wiara kobiety w to, że zostanie uzdrowiona? $\mathrm{Na}$ pewno odpowiedź różniłaby się w zależności od tego, jaką religię wyznawała. Pewna część wierzeń (mimo ścisłego zakazu synkretyzmu u Izraelitów - por. Wj 20 , 3; Pwt 5,7) mogła być też wspólna dla Żydów i pogan, ze względu na przenikanie się kultur. Z pewnością chora wierzyła, że Jezus jest kimś szczególnym, a jej działanie mogło wynikać z popularnego ówcześnie przekonania, że moc i władza osoby są przenoszone na jej szaty ${ }^{15}$. W starożytności wierzono, że władcy czy też duchowi przywódcy zostawiali swoje błogosławieństwo tym, którym udało się ich dotknąć, jak również, że przez dotyk otrzymuje się moc dotkniętej osoby ${ }^{16}$. Jeśli niewiasta była Żydówką, mogła widzieć w Jezusie świętego - reprezentanta Boga na ziemi, który podobnie jak ołtarz w świątyni mógł uczynić świętym tego, kto go dotknął (por. Wj $29,37)^{17}$. Wiara w specjalną moc szat reprezentujących danego człowieka jest dobrze poświadczona w $\mathrm{ST}^{18}$.

Jezus poczuł, że frędzle Jego szat zostały dotknięte przez kogoś z zebranych wokół Niego osób. Jest to niezwyczajne, żeby w napierającym tłumie odczuć tak nieznaczną styczność. Nie jest przypadkiem, że w dłuższych redakcjach tego fragmentu (Mk, Łk) widać szczególny zabieg redaktorów polegający na zrównaniu dotknięcia szaty z dotknięciem samego Jezusa ${ }^{19}$.

Marek informuje, że kobieta dotknęła płaszcza Jezusa (co jednak nie wylklucza, że chodziło o frędzle), Mateusz i Łukasz piszą o dotknięciu „frędzli” ( - takie tłumaczenie ma tez większość polskich przekładów ${ }^{20}$. Czy jednak Mateusz i Łukasz intencjonalnie umieścili to określenie, a według ich relacji, kobieta specjalnie sięgnęła właśnie po tę, a nie inną część stroju? Pojawia się również pytanie, czy możemy być pewni translacji, skoro etymologicznie słowu крá. $\pi \varepsilon \delta 0 \mathrm{v}$ bliższe jest tłumaczenie „brzeg”, „skraj”.

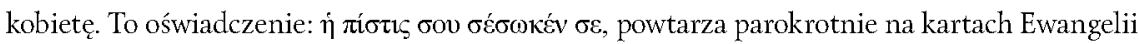
(por. słowa skierowane do grzesznej kobiety: Łk 7, 50, do Bartymeusza: Mk 10, 52; Łk 18, 42 czy do tredowatego: $€ \mathrm{k} 17,19)$.

15 W.L. Lane, The Gospel of Mark, s. 192; H.L. Strack, P. Billerbeck, Kommentar..., s. 520. Podobnie rytualna nieczystość była przekazywana na szaty nieczystej osoby (tak np. Kpł 15, 27; 17, 15).

16 Por. J.R EDwards, The Gospel According to Mark, s. 163.

17 Por. tamże, s. 163-164.

18 Na przykład w $2 \mathrm{Krl} 2$ wody Jordanu rozstępują się po uderzeniu ich płaszczem Eliasza. Także Elizeusz naciska na Eliasza, aby mógł otrzymać część jego płaszcza, a zaraz po jego otrzymaniu zaczyna prorokować (por. $1 \mathrm{Krl}$ 19, 13). Motyw pojawia się też dwukrotnie w $1 \mathrm{Sm}$. Dawid ucina połę płaszcza Saula, a wtedy, jak pisze narrator, ,zadrżało serce Dawida z powodu odcięcia poły należącej do Saula" (1 Sm 24,6). Por. G.H. TwelfrReE, Jesus the Miracle Worker, Downers Grove, IL 1999 , s. 133.

19 U Marka Jezus pyta: „kto dotknął mojego płaszcza?” (5, 30b), a uczniowie odpowiadaja ,pytasz: Kto Mnie dotknął” ( $5,31 \mathrm{~b}$ ); w podobny sposób u Łukasza kobieta „dotknęła frędzli Jego płaszcza” $(8,44)$, a Jezus pyta: „K to się Mnie dotknął?” $(8,45)$ i ponownie powtarza twierdząco: „Ktoś się Mnie dotknął" (8, 46a).

20 Analiza jego możliwych znaczeń poniżej (punkt 2). 
Przyjrzyjmy się, jakie znaczenie miało słowo użyte w tym miejscu przez ewangelistów oraz jaką rolę (nie tylko religijną) mogła odgrywać ta ozdoba w czasach Jezusa w środowisku żydowskim i innych kulturach.

\section{BiBLIJNA TERMINOLOGIA OPISUJĄCA „FRĘDZLE”}

Próbując odpowiedzieć na pytanie, jakiej konkretnie części szaty dotknęła kobieta cierpiąca na krwotok, przeanalizujemy znaczenie greckich terminów zastosowanych przez ewangelistów. Prześledzimy także, gdzie w NT występują takie same określenia i jakie znaczenie mają w tych miejscach. Następnie zwrócimy uwagę na terminologię hebrajską użytą na określenie „frędzli” w passusach zawierających nakaz ich noszenia (Lb 15, 38-40; Pwt 22, 12). Spojrzymy także na polskie odpowiedniki tłumaczące greckie i hebrajskie słownictwo. Na tej podstawie możliwe stanie się wyjaśnienie, czy chora niewiasta dotknęła brzegu płaszcza, ozdoby umieszczonej na skraju szaty, czy też znaku o znaczeniu religijnym - jednego z czterech żydowskich frędzli mocowanych przez Izraelitów na brzegu płaszcza.

\subsection{Słownictwo greckie}

W trzech redakcjach synoptycznych znajdujemy dwa różne ok reślenia części szaty

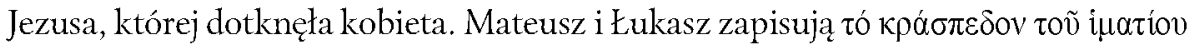
(w tłumaczeniu Biblii Tysiąclecia, wyd. 5: „, frędzle płaszcza”), natomiast Marek ma

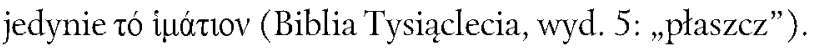

Perykopa ta jest jednym z nielicznych miejsc, w których Mateusz i Łukasz używają wspólnego określenia i różnią się od wersji Marka, który notuje jedynie dotknięcie „płaszcza”. Mateusz wybiera dłuższe wyrażenie, mimo że w całości jego opowiadanie daje wrażenie skrótu historii (jego wersja to mniej niż jedna trzecia redakcji Marka) ${ }^{21}$. Może to być zrozumiałe, gdy przypomnimy o hebrajskich adresatach jego Ewangelii, którzy rozumieją, jakie znaczenie mają frędzle dla pobożnego Żyda $\mathrm{yda}^{22}$. Zastanawiające jest jednak użycie tego samego wyrażenia przez Łukasza, który kierował swoją relację w pierwszym rzędzie do pogan ${ }^{23}$. Mogli oni nie być zaznajomieni z tym żydowskim zwyczajem. Może jednak dla pogan frędzle również miały ogólnie znane znaczenie? Dodatkowo, powszechnie przyjmuje się, że Łukasz (jak i Mateusz) korzystał z wersji pierwotnej, czyli Markowej (w której nie ma określenia „frędzle”), dlatego tym bardziej zastanawia użycie przez niego tego wyrażenia ${ }^{24}$.

21 GNT4: Wersja Mateusza: 48 słów, wersja Marka: 153, wersja Łukasza: 110. Por. R. SCHNACKENBURG, The Gospel of Matthew, Grand Rapids, MI 2002, s. 90.

22 Ustalenie pochodzenia adresatów Ewangelii podaję za ogólnie przyjętą teorią, która bywa kwestionowana. Por. S. GĄDECKI, Wstęp do Ewangelii synoptycznych, Gniezno 1995, s. 57-58.

23 Por. tamże, s. 100-102.

24 Por. D.J. HarRington, The Gospel of Matthew, s. 131. 
Określenie kpá. $\pi \varepsilon \delta \delta o v$ występuje w NT pięć razy i tylko w ewangeliach synoptycznych ${ }^{25}$. Używa go Mateusz, kiedy Jezus zarzuca uczonym w Piśmie i faryzeuszom powiększanie filakterii i wydłużanie frędzli u płaszczy (Mt 23, 5). Paralelne miejsca u Marka i Łukasza (Mk 12, 38; Łk 20, 46) nie zawierają tego rzeczownika, a mówią

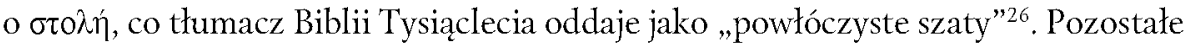
dwa występowania tego słowa to passus w redakcji Marka i Mateusza przypominający historię kobiety cierpiącej na krwotok, który mówi o przynoszeniu do Jezusa chorych i prośbie, by choć „frędzli u Jego płaszcza mogli się dotknąć” (Mk 6, 56; Mt 14, 36).

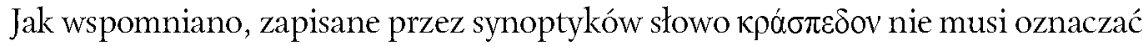
jedynie frędzli (tak ma Biblia Tysiąclecia i większość wspótczesnych polskich tłumaczeń). Dosłownie znaczy bowiem „krawędź”, „kraniec”, „brzeg”, „kkraj”, „rąbek”27. Wyrażenie to składa się z dwóch części: kópa - oznaczające "głowę”, , „szczyt”, „wierzchołek”, oraz $\pi \varepsilon ́ \delta \delta$ - o znaczeniu „ziemia”, „grunt”" Wydaje się jednak, że w czasach Jezusa oba znaczenia ( „brzeg” i „frędzel”) w odniesieniu do szaty żydowskiej bywały synonimami ${ }^{29}$. Wskazywałoby na to tłumaczenie LXX, które w tekście nakazującym Żydom noszenie frędzli (Lb 15, 38-40; Pwt 22, 12) to hebrajskie słowo oddaje właśnie określeniem $\kappa p a ́ \sigma \pi \varepsilon \delta \delta$.

\subsection{Słownictwo hebrajskie}

W ST nakaz noszenia frędzli pojawia się dwukrotnie. Pierwszy - bardziej szczegółowy-zawarty jest w Lb 15, 38-40, drugi w Pwt 22, 12. Określenia hebrajskie użyte w tych miejscach na oznaczenie frędzli różnią się. Lb ma צִיצִ, podczas gdy Pwt używa פָָָּּּ (tak zarędzle mają zostać umieszczone na brzegach 15, 38,

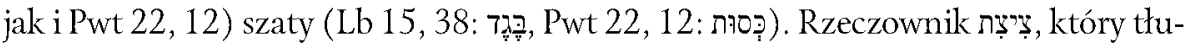
maczony jest jako „kędzior”, „chwost”, „frędzel”, „, nitki widoczne” 30 , pochodzi od słowa ب̣ ( „kwiat”, „piórko”, „,krzydło”), do którego dodana została żeńska końcówka przymiotnikowa. Oznacza w pierwszym rzędzie „coś jak kwiat” lub ,jak piórko”"11.

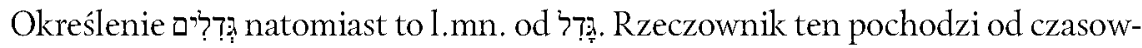

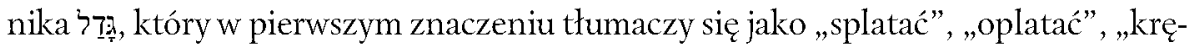
cić” ${ }^{32}$. A zatem

25 Trzy razy u Mateusza, raz u Marka i raz u Łukasza.

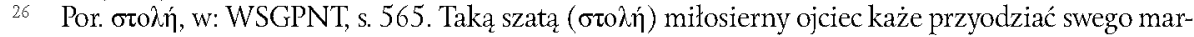
notrawnego syna (por. Łk 15, 22). U Marka nosi ją młodzieniec, którego widzą niewiasty w grobie po zmartwychwstaniu Jezusa (por. Mk 16,5).

27 Por. кpá $\sigma \pi \varepsilon \delta o v, w:$ WSGPNT, s. 346.

28 Por. tamże, кápa, $\pi \dot{\varepsilon} \delta$ ov, s. 316, 479.

29 Por. A.K. Grover, The Dress of the Master, „The Biblical World” 15/5 (1900), s. 354.

30 Por. S.P.D. DE VRIEs, Obrzędy i symbole Żydów, thum. A. Borowski, Kraków 2001, s. 82.

31 Por. ציצ: BDB, s. 847.

32 Por. לㄹ, w: BDB, s. 152.

33 Por. S. Bertanan, Tasseled Garnents in the Ancient East Mediterranean, "The Biblical Archaeologist" 24/4 (1961), s. 119. Trzeba zauważyć, że znaczenie obu słów jest nieco odmienne. We współczes- 
Oba określenia ( $z$ Pwt i z Lb) są słowami rzadko stosowanymi w ST. Oprócz nakazu noszenia frędzli צִיצִ występuje tylko raz (w Ez 8, 3) na określenie splotu włosów. Tak samo בְִּדְלים pojawia się w ST jeszcze raz (w $1 \mathrm{Krl} 7,17$ ), na określenie architektonicznego detalu - ozdoby na zwieńczeniu kolumny.

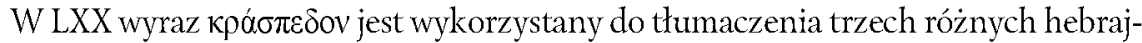
skich określeń. Występuje we wspomnianych miejscach zawierających nakaz noszenia frędzli (Lb 15, 38-40; Pwt 22, 12) i w Za 8, 23. W Lb 15, 38-40 tłumaczy słowo

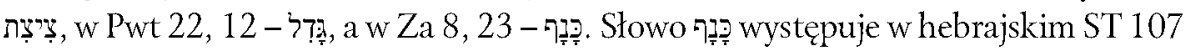
razy i oznacza „kraniec”, „brzeg”, „skrzydło”, „połę”. 14 razy jest używane na ozna-

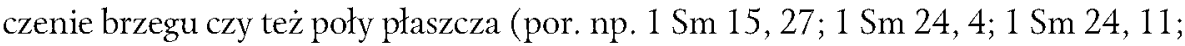
Jr 2, 34; Ag 2, 12; Rt 3, 9), ale tylko raz przetłumaczone jest jako $\kappa \rho a ́ \sigma \pi \varepsilon \delta o v^{34}$. W Za 8,23 „poła” albo „kraj” jest dla aleksandryjskiego tłumacza synonimem frędzli. Wydaje się, że nie tylko w tym miejscu, ale także w innych, gdzie określenie odnosi się do szat, jest traktowane jako równoznaczne $z$ frędzlami, a przynajmniej zawierające w domyśle frędzle, które zawsze ozdabiały brzeg żydowskiego płaszcza. Odciać połę płaszcza, jak w $1 \mathrm{Sm} 24$, 4, znaczyło zatem odciąć jego brzeg wraz z frędzlami ${ }^{35}$.

\section{Biblijny NakAZ NOSZENIA FRĘDZLI}

\subsection{Prawa Pięcioksięgu (Lb 15, 37-40; Pwt 22, 12)}

Z obu miejsc Tory, w których znajdujemy zapis nakazu noszenia frędzli (Lb 15, 37-40 i Pwt 22, 12), tylko Lb wyjaśnia ten zwyczaj. Tłumaczy, jaki jest cel noszenia frędzli, choć nie mówi, dlaczego ma to być akurat ta ozdoba. Trzeba jednak pamiętać, że „godną uwagi właściwością Pentateuchu jest to, iż z rzadka tylko objaśnia swo-

nym języku polskim brakuje określeń, które by je rozróżniały, dlatego oba oddane są za pomocą słowa "frędzle". Jednak określenie צִִ צִ oznacza raczej pojedynczy frędzel w formie rozchylającego się kielicha kwiatu, natomiast ą̧ skłania się ku oznaczeniu skręconych nici na brzegu materiału, tworzących rodzaj obramowania. Przeglądając polskie tłumaczenia ST, w większości znajdujemy jedno słowo „frędzle”. Rozróżnienie istnieje w starszych przekładach: Biblii Wujka (1599, bramy - sznurki), Biblii Gdańskiej (1632, strzępki - sznurki), przekładzie Izaaka Cylkowa (1883/1914, strzępki - sznurki), przekładzie Pięcioksięgu J. Miesesa (1931, kiście - sznurki). Ze względu na archaiczny język nie pomagają one obecnie w rozróżnieniu tych dwóch określeń. Pojedynczy frędzel w języku polskim mogło oddawać słowo „chwost”, jednakże zwykle dotyczyło ono tylko ozdobnego zakończenia sznura. Poprawnym określeniem, które jednak ze względu na zmiany semantyczne, jakie zaszly w języku polskim, nie jest używane, byłoby ok reślenie „,kutas" (por. Kutas, w: Stownik jezzyka polskiego, red. J. Karłowicz, A. Kryński, W. Niedźwiedzki, t. 2, Warszawa 1902, s. 664).

34 Por. ๆִ

35 Por. F.J. STEPHEns, The Ancient Significance of Sị̂sith , „Journal of Biblical Literature” 50/2 (1931), s. 69. 
ją własną symbolikę (...). Tak samo jest (...) z tym frędzelkiem i widoczną w nim błękitną nitką" ${ }^{36}$.

Lb 15, 37-40 podaje wyjaśnienie, które układa się w pewien proces. Kiedy Izraelita spojrzy na frędzle, przypomni sobie o przykazaniach Pana, aby je wypełnić, i to będzie antidotum na skłonność do podążania za żądzami własnego serca i oczu. Wypełniając przykazania, Izraelita stanie się świętym.

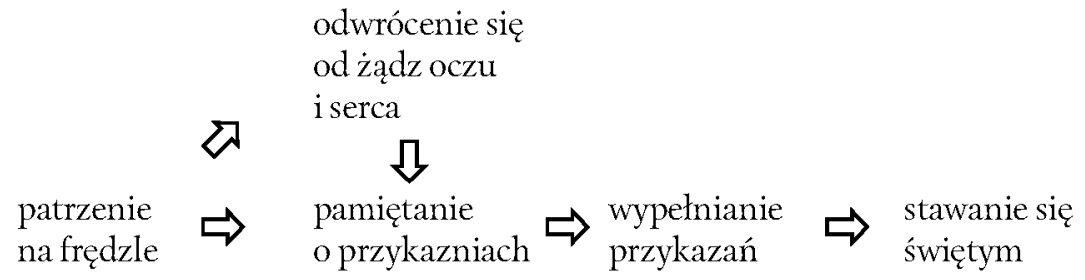

\section{Noszenie frędzli a proces uświęcania Izraelity}

Tekst hebrajski Lb 15, 39 dosłownie stwierdza: „I będą wasze frędzle, i będziecie widzieli go". W odniesieniu do frędzli występuje zaimek "go" (l.poj., r.m.) w miejsce spodziewanego ,je" (1.mn., r.ż.). Literatura judaistyczna zwraca uwagę na ten szczegół i wyjaśnia, że poprzez wypełnianie przykazania noszenia frędzli można nauczyć się dostrzegać Boga i pamiętać o wierności wobec Niego ${ }^{37}$. Frędzle miały sprawić, aby przy każdym wkładaniu ubrania Żyd przypominał sobie, że należy do Boga i jest zobowiązany do przestrzegania Bożych przykazań ${ }^{38}$. Ozdoba ta miała zatem ogromne znaczenie z religijnego punktu widzenia. Niekiedy domniemywa się, że również kobiety, dzieci i niewolnicy nosili frędzle, choć nie było to od nich wymagane ${ }^{39}$.

\subsection{Rabiniczna interpretacja nakazu}

Późniejsza żydowska interpretacja nakazu noszenia frędzli podaje szczegółowe wyjaśnienia co do zasad noszenia tej ozdoby ${ }^{40}$. Drobiazgowość regut jest duża, choć nie wyróżnia się na tle skrupulatności innych żydowskich norm. W talmudycznym traktacie Menachot znajdziemy dyskurs na temat tego, czy nakaz noszenia frędzli dotyczy także osoby niewidomej (skoro Pan przykazuje Izraelicie patrzenie na ozdobę); czy należy posiadać frędzle także przy nocnej szacie (skoro w nocy i tak nic nie

S.P.D. DE VRIES, Obrzędy i symbole Żydów, s. 84.

Por. Tora Pardes Lauder. Bemidbar, red. i tłum. S. Pecaric, Kraków 2005, s. 125; b. Men. 43b.

Por. W. Barclay, The Gospel of Luke (The New Daily Study Bible), Louisville, KY 2001, s. 134.

39 Por. T. Lewis, Origines Hebraeae: The Antiquities of the Hebrew Republic in Four Books, London 1724, s. 228. b.Men. 43a ukazuje różne poglądy na tę kwestię.

40 Por. B.Z. BokseR, The Thread of Blue, „Proceedings of the American Academy for Jewish Research" 31 (1963), s. 1. 
widać); czy należy je nosić, jeśli szata ma pięć rogów albo tylko trzy (skoro wymóg mówi o przymocowaniu frędzli do szaty o czterech rogach $)^{41}$. Przed założeniem szaty z frędzlami należy odmawiać modlitwę Szema ${ }^{42}$. Można ją jednak wypowiadać od momentu, kiedy jest na tyle jasno, że da się odróżnić nić niebieską (we frędzlach) od nici białych ${ }^{43}$.

Płaszcz noszony przez Żydów czasów Jezusa był kwadratową płachtą materiału $z$ wyciętym na środku otworem na głowę ${ }^{44}$. Na czterech jej rogach umieszczano frędzle ${ }^{45}$. Składały się one z czterech (zwykle wełnianych) nici- trzech białych (jedna była dłuższa od pozostałych) i jednej niebieskiej ${ }^{46}$. Przewlekano je przez otwór w rogu szaty, tak że zwisało osiem końców. Splatano je, a następnie związywano w określony sposób, tworząc węzełki, i okręcano wystającym fragmentem dłuższej nici ${ }^{47}$. Węzełków na jednym rogu było 39. Jest to liczba, którą dają zsumowane wartości liczbo-

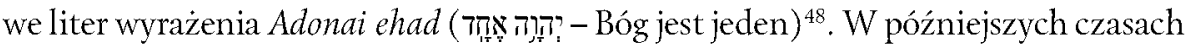
frędzle zaczęto nosić jedynie do modlitwy oraz przy spodnim ubraniu, ale za czasów Jezusa noszono je na zewnątrz i były one powodem chluby ${ }^{49}$.

Obecnie frędzle nosi się do modlitwy na brzegach tzw. tallit gadol oraz noszonego jako spodnie ubranie tallit katan (mały tallit, popularnie nazywany po prostu cicit) ${ }^{50}$. Jest dyskutowane, czy cicit oznaczało frędzle dokoła brzegu ubrania, czy raczej po jednym frędzlu na czterech rogach. Nici mogły też być skręcone w grupach, aby utworzyć chwost $\mathrm{z}$ frędzellków. W każdym frędzlu miała zostać umieszczona niebieska nićs1.

Jedynie zobowiązanie z Lb mówi o niebieskim (fioletowym) kolorze używanego sznurka. Barwa ta ma przypominać morze, które z kolei ma przywodzić na myśl kolor nieba, a ten - kolor Tronu Chwały ${ }^{52}$. To stopniowanie odniesienia barwy do kolej-

41 Por. b.Men. 42b-43a.

42 Por. b.Ber. $9 \mathrm{~b}$.

43 Por. b.Men. $43 \mathrm{~b}$.

44 Por. A.K. Glover, Modem Jewish Customs as Possible Helps in Bible Study, „The Biblical World” $18 / 1(1901)$, s. 8 .

45 Por. J. PhilliPs, Exploring the Gospel of Matthew (The John Phillips commentary series), Grand Rapids, MI 2005, s. 168. Według Glovera, szkaplerz noszony przez chrześcijańskich mnichów można historycznie połączyé z żydowskim płaszczem o czterech rogach. Rzeczywiście, krój szkaplerza przypomina obecny żydowski mały tallit. Prawdopodobnie oba stroje pochodzą od żydowskiej zewnętrznej szaty z frędzlami. Por. A.K Glover, Modern Jewish Customs as Possible Helps in Bible Study, s. 8-9.

46 Por. W. Barclay, The Gospel of Luke, s. 134.

47 Por. S.P.D. DE VRIEs, Obrzędy i symbole Żydów, s. 86.

48 Por. tamże.

49 Jezus krytykuje uczonych w Piśmie, którzy „wydłużają frędzle u płaszczów”, aby się pokazać (Mt 23, 5b). Por. W. Barclay, The Gospel of Luke, s. 134.

50 Por. A.K. Glover, The Dress of the Master, s. 353-356.

51 Por. w: TWOT, sekc. 1912.0.

52 Por. b.Men. 43b, Tora Pardes Lauder. Bemidbar, s. 124. Wyczerpujący opis symboliki koloru niebieskiego oraz samego barwnika używanego do farbowania nici frędzli podaje B.Z. BoKSER, The Thread of Blue, s. 1-32. 
nych niebieskich przestrzeni (morze, niebo, Tron Chwały) ma wskazywać, że droga do najwyższych poziomów duchowości jest stopniowa, trudna i połączona $z$ wysił$\mathrm{kiem}^{53}$. Zadaniem niebieskiego koloru jest także przypominanie o boskim wybraniu Izraela i bliskości z Tym, który zamieszkuje niebiosa ${ }^{54}$. Niebieski barwnik, którym farbowano nić wplataną do frędzli, otrzymywano z mięczaków Murex trunculu ${ }^{55}$. Był on bardzo drogi. Koszt wynikał po pierwsze z ogromnej ilości muszli, które należało pozyskać (do otrzymania 1 grama pigmentu potrzebne było ok. 8 tysięcy muszli) ${ }^{56}$; po drugie z trudności połowu mięczaków (ich napływ był sporadyczny i nieregularny); a po trzecie ze skomplikowanej techniki produkcji samego barwnika ${ }^{57}$. Podczas gdy nakaz noszenia niebieskiej nici wplecionej we frędzle zakładał, że każdego Izraelitę będzie stać na zakup przynajmniej czterech takich nici, to jednak z biegiem czasu ten stan rzeczy się zmienił - cena rosła do nieosiągalnego dla przeciętnego Żyda poziomu. W tym czasie pojawiły się twierdzenia, że do wypełnienia przykazania noszenia frędzli wystarczy nić w jednym $z$ dwóch wskazanych kolorów (biały, niebieski). To po części było przyczyną, że niebieski sznurek zniknął z frędzli ${ }^{58}$. Nie zanotowano prób zamiany kosztownego barwnika na inny, którego produkcja byłaby tańsza (choć technicznie było to możliwe). Nie zaprzestano jednak dyskusji nad znaczeniem niebieskiego koloru nici ${ }^{59}$. Istotne jest, czy w czasach Jezusa do frędzli wplatano jeszcze niebieską nić zgodnie z nakazem Lb 15,37-40, czy też nie, oraz czy na znaczenie frędzli wpływała obecność tejże.

Wydaje się pewne, że w czasach Jezusa praktyka noszenia frędzli pokrywała się z biblijnymi nakazami. W grotach nad Morzem Martwym odkryto pochodzace z czasów Bar-Kochby (ok. 135 rok po Chr.) frędzle wykonane $z$ białego Inianego sznurka

53 Por. Tora Pardes Lauder. Bemidbar, s. 124.

54 Por. J. PHiLuPs, Exploring the Gospel of Matthew, s. 168.

55 Są to mięczaki z rodziny rozkolcowatych. Wydzielają one barwnik (tzw. purpurę tyryjską), który pod wpływem światła z żółtego przechodzi w fioletowy.

56 Por. B.Z. Bokser, The Thread of Blue, s. 2-3.

57 Por. tamże, s. 2; B. Goonnick, The Tassel and the Blue Cord, „Jewish Bible Quarterly” 21/2 (1993), s. 102-103; J. Milgrom, Of Hems and Tassels, „Biblical Archaeology Review” 9/3 (1983), s. 62; J.H. Walton, V.H. Matthews, M.W. Chavalas, Komentarz historyczno-kulturowy do Biblii Hebrajskiej (PSB 24), Warszawa 2005, s. 154.

58 Innym powodem był spór między szkołą Hillela i Szammaja dotyczący materiału, z którego wytwarzano niebieską nić. Szkoła Szammaja uważała, że nie jest możliwe stosowanie niebieskiej nici wykonanej z wełny do lnianego ubrania, gdyż było to przeciwne przykazaniu z Pwt 22, 11 zakazującemu łączenia w jednym ubiorze różnych materiałów. Szkoła ta uznawała ten zakaz za ważniejszy od nakazu dodawania niebieskiej nici do frędzli. Wprawdzie Prawo uznało rację szkoły Hillela, znosząc zakaz łączenia różnych materiałów w odniesieniu do frędzli, ale praktyka poszła za ustaleniami szkoły Szammaja. Jeśli chodzi o zastępnik drogiego barwnika, to istniał róslinny, ale jego stosowanie w przypadku barwienia nici przeznaczonych do kultu było zakazane. Por. B.Z. BOKSER, The Thread of Blue, s. 22-23.

59 Warto przypomnieć, że błękitny w połączeniu z białym (zgodnie z nakazem Lb 15, 37-40) współcześnie są kolorami flagi Izraela. Por. tamże, s. 32. 
oraz wełnianych niebieskich nici ${ }^{60}$. Jacob Milgrom stwierdza, że zwyczaj wplatania niebieskiej nici do frędzli zarzucono niedługo po powstaniu Bar-Kochby ${ }^{61}$. Jednak istnieją dowody importu niebieskiego barwnika $z$ Babilonii do Palestyny jeszcze w VI wieku po Chr. Wraz z ogarniającymi świat śródziemnomorski podbojami islamskimi w VII/VIII wieku przemysł jego wydobycia i produkcji został prawie całkowicie zniszczony. Istnieje niepotwierdzona teoria, że niebieska nitka znikła z frędzli żydowskiego płaszcza dopiero w tym czasie ${ }^{62}$.

Niezależnie jednak od tego, czy niebieska nić zanikła już w II wieku po Chr., czy też później, możemy uważać, że kobieta cierpiąca na krwotok widziała ją we frędzlach płaszcza Jezusa, po które sięgała. Fragment Mk 6, 56 (por. Mt 14,36) ukazuje, że dotknięcie tej części szaty było ważne nie tylko dla tej konkretnej niewiasty, gdyż ówczesna społeczność zdawała sobie sprawę, że dotknięcie frędzli mogło być ratunkiem dla osób potrzebujących pomocy (por. Mk 6, 56). Obecny w nich niebieski kolor mógł wpływać na odnoszenie spodziewanego ratunku do Boga, a nie do jakiejś cudownej, magicznej mocy, którą frędzle mogłyby przekazywać.

\section{WYSTĘPOWANIE I ZNACZENIE FRĘDZLI W STAROŻYTNOŚCI}

\subsection{Frędzle poza Izraelem}

W starożytnym świecie status danej osoby, jej religia, kultura oraz majętność były anonsowane poprzez ubiór. Rodzaj płaszcza, materiał, z którego był wykonany, oraz noszone ozdoby przekazywały informacje na temat ich właściciela. Niektóre elementy szaty miały także znaczenie ochronne - strzegły przed złymi duchami czy wpływem zaklęć. W dużo mniejszym stopniu niż obecnie sposób ubierania był świadectwem indywidualnego stylu. Znacznie częściej stanowił swego rodzaju przekaz kulturowy, swoisty język, poprzez który człowiek przedstawiał siebie społecznoścíi ${ }^{63}$.

$\mathrm{Na}$ całym Bliskim Wschodzie frędzle były częstą ozdobą ubrań ${ }^{64}$. Istnieją sugestie, że korzenie żydowskich cicit są dużo starsze od nakazu ich noszenia znajdujące-

60 Jak wspomniano, połączenie lnu i wełny do uszycia szaty było zakazane przez Prawo (Pwt 22, 11). Wydaje się, że takie połączenie było uznawane za święte i dlatego zabronione w przypadku świeckich szat. Kombinacja różnych materiałów była stosowana w przypadku szat i tkanin przeznaczonych do kultu, wykorzystywanych w świątyni i szat kapłańskich (np. wykonanie efodu - Wj 28,6 , oraz pasa do przewiązywania tuniki kapłana - Wj 39, 29). Prawdopodobnie z tego właśnie powodu niebieska wełniana nić była używana do splatania lniano-wełnianych frędzli, które były traktowane jako element przeznaczony do kultu. Por. J. Mirgrom, Of Hems and Tassels, s. 65.

61 Por. tamże, s. 63.

62 Por. B.Z. Bokser, The Thread of Blue, s. 29-30.

63 Por. A.J. BAtTen, Clothing and adomment, „Biblical Theology Bulletin” 40/3 (2010), s. 148.

64 Por. F. Mickiewicz, Ewangelia wedlug świętego Eukasza, rozdziały 1-11. Wstęp, przekład z oryginatu, komentarz (NKBNT 3), Czestochowa 2011, s. 451. 
go się w Torze, a ich szerokie zastosowanie w wielu starożytnych kulturach mogłoby tę teorię potwierdzać. Poszukiwanie celu przymocowywania frędzli do kraju płaszcza prowadzi do odkrycia w tej praktyce sensu magicznego, opartego na przesądach ${ }^{65}$.

Dowody noszenia frędzli na starożytnym Wschodzie pochodzą zarówno z zachowanych świadectw pisanych, jak i różnego rodzaju przedstawień artystycznych ukazujących postaci ludzkie i boskie w szatach ${ }^{66}$. Przykładami mogą być: statua akadyjskiego zarządcy Mari Puzur-Isztara (ok. XX wieku przed Chr.) z widocznymi frędzlami wzdłuż dolnej krawędzi wierzchniej szaty, egipskie malowidła z grobowca Khnumhotepa II (ok. XIX wieku przed Chr.) ukazujące postaci w szatach ze sznurkowymi frędzlami czy płaskorzeźba z Nimrud, na której płaszcze Aszurnasirpala II (IX wiek przed Chr.) i jego ducha opiekuńczego ozdobione są frędzlami (obaj mają je także przy szyi ${ }^{67}$. Frędzle widzimy również na minojskich pieczęciach kamiennych z XVII wieku przed Chr., jak też na asyryjskich płaskorzeźbach z IX wieku przed Chr. ${ }^{68}$. Jak wspomniano, ozdobna krawędź szaty nie była jedynie dekoracją, ale przede wszystkim oznajmiała status osoby. Frędzle wykonane $z$ drogich materiatów należały do tego typu dekoracji (stąd $\mathrm{u}$ Żydów ów drogocenny niebieski barwnik). Im bardziej wyszukana i kosztowna była ta ozdoba, tym wyższą pozycję osoby oznaczała $^{69}$. W powyższych przykładach nie mamy jednak do czynienia z pojedynczymi frędzlami w rogach szaty, ale z całym brzegiem płaszcza ozdobionym licznymi drobnymi sznurkami.

O frędzlach mocowanych na rogach płaszcza (takich jak opisane w Lb i Pwt) możemy mówić dopiero w przypadku malowideł w grobowcach Rechmirego oraz Menkheperreseneba (XV wiek przed Chr.) w Tebach. Na malowidłach widać postaci Syryjczyków ubranych w długie szaty, wyraźnie podzielone na części stanowiące poły płaszcza. Na dolnym brzegu płaszcza, w rogach tych pół, umieszczone są pojedyncze frędzle $w$ formie chwostu. Widoczne są trzy frędzle, ale ponieważ są to malowidła dwuwymiarowe, nie wiemy, czy artysta widział kolejny, czwarty, na tyle szaty. W obu przypadkach zachowały się barwy malowideł i widać, że frędzle były albo niebieskie, albo czerwone ${ }^{70}$. Interesujące są także egipskie malowidła ścienne z czasów Setiego I (XIV-XIII wiek przed Chr.). Przedstawiają dwóch mężczyzn noszących krótką (do kolan) spódnicę, której dolny brzeg składa się z trzech zębów przypominających skrzydła. Z każdego tak utworzonego rogu zwisa sznurek zakończony frędzlem. Tak jak w poprzednim przypadku, nie możemy powiedzieć, czy z tyłu było czwarte skrzydło $z$ jeszcze jednym frędzlem (choć biorąc pod uwagę spodziewaną symetrię ubiorów, można tak domniemywać). Podobne ząbkowane szaty z przycze-

\footnotetext{
Por. F.J. Stephens, The Ancient Significance of Sịșîth, s. 60.

Por. S. Bertman, Tasseled Garments in the Ancient East Mediterranean, s. 119-128.

Podaję za: tamże, s. 120.

Por tamże.

Por. J. Milgrom, Of Hems and Tassels, s. 62.

70 Por. S. BerTman, Tasseled Garments in the Ancient East Mediterranean, s. 122-124.
} 
pionymi pojedynczymi frędzlami noszą przedstawieni na egipskich reliefach jeńcy wojenni wzięci do niewoli przez armię faraona Ramzesa III (XII wiek przed Chr.). Część archeologów widzi w nich Filistynów, ze względu na charakterystyczne hełmy z piórami, które noszą na głowach ${ }^{71}$.

$Z$ frędzlami możemy spotkać się także na egipskich stelach przedstawiających bogów Raszefa oraz Seta. Warto zaznaczyć, że pierwotnie Raszef nie był bóstwem egipskim, a kananejskim. Jego kult w starożytności był szeroko rozpowszechniony na terenie Syropalestyny oraz w Grecji i dotarł do Egiptu ok. XV wieku przed Chr. ${ }^{72}$. $\mathrm{Na}$ odkrytych malowidłach i stelach często jest on przedstawiany w stroju z pojedynczymi zwisającymi frędzlami ${ }^{73}$.

Również w przedstawieniach pochodzących ze starożytnej Grecji możemy znaleźć ubiór ozdobiony frędzlami. Na amforze z Pontu (VI wiek przed Chr.) widzimy bogów panteonu greckiego noszących ubiór z dodanymi, pogrupowanymi po trzy lub cztery, frędzlami w rogach szat ${ }^{74}$.

Przedstawienia szat $z$ frędzlami w sztuce egipskiej dotyczą prawie wyłącznie postaci pochodzenia pozaegipskiego (oprócz boga Seta). Z dostępnych świadectw wynika, że pojawiają się one w sztuce ok. XV/XIV wieku przed Ch. ${ }^{75}$. Natomiast jednym z najwcześniejszych odwzorowań frędzli noszonych przez Izraelitę jest postać króla Jehu, ubranego w szatę przepasaną sznurem. Na jej brzegu widnieją drobne frędzle, także na końcach sznura widać pojedyncze chwosty ${ }^{76}$.

Od strony językowej akadyjskie sisiktu określające ozdobę brzegu szaty wydaje się być synonimem hebrajskiego cicit (צִִיצִ ${ }^{77}$. O niezwyczajnym znaczeniu tego dodatku do płaszcza możemy dowiedzieć się z akadyjskich tabliczek z Nuzi, zapisanych przez huryckich pisarzy babilońskim pismem klinowym, datowanych na XV-XIV wiek przed $\mathrm{Ch}^{78}{ }^{78}$. Te pozabiblijne teksty pokazują, że ozdobny brzeg szaty był uważany za symboliczne przedłużenie samego właściciela stroju, a szczególnie za wyraz jego autorytetu i pozycji ${ }^{79}$.

71 Podobne przedstawienia na płytkach z kości słoniowej z ok. X wieku przed Chr. odkryto w Meggido. Por. tamże, s. 124.

72 Por. M. J. MudLeR, ףש̛ר rešep, w: Theological Dictionary of the Old Testament, red. H. Ringgren, G.J. Botterweck, H.-J. Fabry, t. 14, Grand Rapids, MI 2004, s. 10-16. Więcej informacji na temat tego bóstwa można znaleźć w pracy M. MünNıch, Reszef - bóg starożytnego Orientu (Studia Historico-Biblica 3), Lublin 2011.

73 Por. S. Bertman, Tasseled Garments in the Ancient East Mediterranean, s. 126.

74 Por. tamże, s. 127.

75 Por. tamże, s. 128.

76 Podobną szatę nosi asyryjski monarcha, któremu król Jehu oddaje hołd. Odwzorowanie to znajdujemy na tzw. czarnym obelisku Salmanasara III z IX wieku przed Chr. Podaję za: B. GoodnICK, The Tassel and the Blue Cord, s. 101.

77 Por. F.J. STEPhEns, The Ancient Significance of Sị̂sitith, s. 60-61.

78 Interesujące nas informacje pochodzą przede wszystkim z odczytanych kontraktów handlowych oraz tekstów kultycznych zaklęć.

79 Por. J. Milgrom, Of Hems and Tassels, s. 61. 
Frędzle płaszcza, czy też ozdobny brzeg o szczególnym znaczeniu, były elementem ubioru bogów i mężczyzn. Teksty mówią o chwyceniu sisiktu bóstwa. Ten gest miał przynieść modlącemu się błogosławieństwo. Prawdopodobnie chodziło o dotknięcie frędzli szaty, w którą była ubrana figura przedstawiająca boga. Był to akt o magicznym znaczeniu - miał przekazywać boską moc. Znane są opisy, iż król chwytał te frędzle, co skutkowało obdarzeniem go specjalną łaską bóstwa i przekazaniem mocy do wykonania nadzwyczajnych zadań ${ }^{80}$. Spotkać można także zapis mówiący o chwytaniu za frędzle bożka w celu uniknięcia grzechu. Był to zatem zarazem magiczny ryt, jak i swego rodzaju akt religijny, wyrażający błagalną prośbę.

Opis podobnego gestu (uchwycenia za frędzle), tym razem w odniesieniu do płaszcza człowieka, można znaleźć na tabliczkach z Nuzi zawierających kontrakty handlowe. Wynika z nich, że uchwycenie za brzeg płaszcza dawało pewną władzę nad właścicielem szaty. Zdarzało się też, że przekazanie drugiej osobie frędzli symbolizowało nadanie pełnomocnictwa ${ }^{81}$.

Z tabliczek dowiadujemy się również, że frędzle były wykorzystywane jako rodzaj pieczęci. Ich końce, podobnie jak pieczęć, były odciskane w miękkim materiale tabliczek, który po wyschnięciu ukazywał unikalny układ sznurków, charakterystyczny dla właściciela frędzli ${ }^{82}$.

Innym istotnym faktem jest znaczenie rozdarcia czy też oderwania frędzli. $\mathrm{Na}$ tabliczkach z Mari ( $z$ XVIII wieku przed Chr.) znajdujemy często powtarzające się określenie sisikta bataku - odciąć frędzle ${ }^{83}$. Specjalne zaklęcia chroniły mężczyznę przed rozdarciem sisiktu przez podstępnego czarownika ${ }^{84}$. Także przy uwalnianiu od złego ducha egzorcysta odcinał brzeg szaty dręczonej osoby, a następnie wypowiadał nad nim odpowiednie zaklęcie ${ }^{85}$. Rozdarcie brzegu ubrania żony przez jej męża stanowiło poświadczenie rozwodu i oddalenia kobiety. Być może było to związane ze zmianą statusu społecznego - kobieta przestawała należeć do swojego męża i dlatego niszczył on to, co o tej przynależności mogło świadczyć - frędzle ${ }^{86}$.

80 Nabuchodonozor, sięgając po frędzle Marduka, stwierdza: „ponieważ uchwyciłem frędzli mojego pana Marduka, on mnie ukochał, powierzył mi odnowienie świątyń i odbudowę ruin" - napis na cylindrze Nabuchodonozora II; por. L. ABEL, H. WINCKLER, Keilschriftexte zum Gebrauch bei Vorlesungen, Berlin 1890, s. 37-38, za: F.J. STEPHENs, The Ancient Significance of Sị̂̂îth, s. 62.

81 Jedna z tabliczek opisuje, że dłużnik oddaje dług nie temu, kto pożyczył mu pieniądze, ale osobie trzeciej. Powodem jest fakt, że ta osoba chwyciła za frędzle płaszcza wierzyciela. Por. tamże, s. 63.

82 Por. tamże, s. 63-64.

83 Por. J. Milgrom, Of Hems and Tassels, s. 61.

84 Por. F.J. STEPHENS, The Ancient Significance of Sịsitith, s. 65.

85 Por. J. Milgrom, Of Hems and Tassels, s. 61.

86 Por. F.J. Stephens, The Ancient Significance of Șișîth, s. 65. 


\subsection{Frędzle dla Izraelitów według Starego Testamentu}

Zwyczaj ozdabiania płaszcza frędzlami Izraelici odnosili bezpośrednio do dwukrotnie wyrażonego w Torze nakazu danego przez Boga. Jest jednak prawdopodobne, że nieobce im było także ich symboliczne znaczenie, podobne do tego, jakie nadawały im okoliczne narody. Przykładem może być choćby fragment Za 8, 22-23. Biblia Tysiąclecia, wyd. 5, tłumaczy: „I tak liczne ludy i mnogie narody przychodzić będą, aby szukać Pana Zastępów w Jeruzalem i zjednać sobie przychylność Pana. Tak mówi Pan Zastępów: »W owych dniach dziesięciu mężów ze wszystkich narodów i języków uchwyci się skraju płaszcza człowieka z Judy, mówiąc: Chcemy iść z wami, albowiem zrozumieliśmy, że z wami jest Bóg«". Jak zauważono wyżej (punkt 2), LXX wymie-

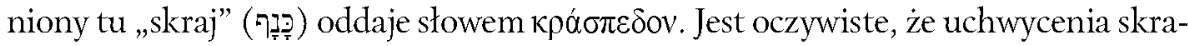
ju płaszcza, o którym mówi tekst, nie należy rozumieć dosłownie. Już w pierwszych wiekach chrześcijaństwa fragment ten odczytywany był jako zapowiedź mesjańska, wypełniona w opisie Mk 6, 56 (wszyscy chorzy, którzy dotknęli choć frędzli płaszcza Jezusa, zostali uzdrowieni) czy właśnie w passusie o kobiecie cierpiącej na krwotok ${ }^{87}$.

Celem gestu uchwycenia za kraj płaszcza jest - jak podaje Za 8, 21-22 - ,zjed-

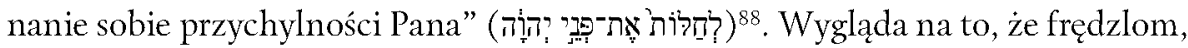
które nosi człowiek z Judy, nadane jest znaczenie podobne do tego, które opisaliśmy w przypadku dotknięcia frędzli bóstwa w świecie pogańskim. Gest ten może skłonić Boga do przychylności wobec człowieka i udzielenia mu błogosławieństwa. Frędzle przekazują Bożą łaskę.

W 1 Sm 15, 27 Saul po grzesznym uczynku (bojąc się ludu, usłuchał jego głosu, zamiast być posłusznym słowu Boga) prosi Samuela, aby poszedł z nim oddać pokłon Panu, ale Samuel odmawia. Wtedy Saul chwyta za kraj jego płaszcza (פָָָָּ) i go rozrywa. Król ponawia prośbę, a Samuel w zaskakujący sposób zmienia zdanie i zgadza się na pójście z Saulem. Jest możliwe, że ta radykalna zmiana spowodowana jest symbolicznym znaczeniem rozerwania brzegu płaszcza - przez ten gest Saul uzyskuje swego rodzaju moc i władzę nad Samuelem.

Podobną historię znajdujemy w $1 \mathrm{Sm}$ 24, 1. Dawid wchodzi do groty, w której

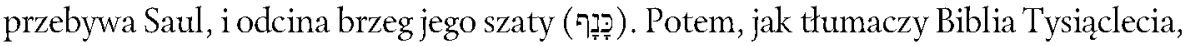

87 Por. B. BAERT, Touching the Hem: The Thread between Garment and Blood in the Story of the Woman with the Haemorrhage (Mark 5: 24b-34parr), „Textile: The Journal of Cloth and Culture” 9 (2011), s. 320 .

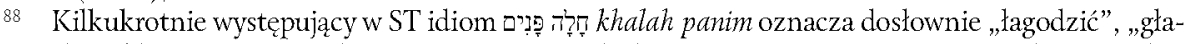
skać oblicze". W ST nigdy nie jest używany w dosłownym znaczeniu, a w sensie zjednywania kogoś, upraszania jego łaski. Pojawia się w kontekście modlitwy (Wj 32, 11; 34, 24; Ps 119, 158), błagania (Za 8,21-22), pokornej prośby ( $2 \mathrm{Krn} 3,12)$ oraz wyrażenia nawrócenia (Dn 9, 13; Jr 26, 19). Zwrot jest podobny do „szukania oblicza Pana”. Por. komentarz do Jr 26, 19 w: The NET Bible, New English Translation Bible, https://netbible.org/bible/Jeremiah+26 (10.06.2019); D.L. Petersen, Haggai and Zechariah 1-8: A Commentary (The Old Testament Library), Philadelphia 1984, s. 320. 
wyd. 5: „zadrżało serce Dawida z powodu odcięcia poły należącej do Saula” (1 Sm $24,5)$. Nie był to zatem czyn bez znaczenia, ani tym bardziej - jak się czasem zakłada - gest mający ukazać dobrą wolę Dawida i brak złych intencji względem króla. Jeśli przyjmiemy, że dla Izraelitów brzeg płaszcza stanowił swego rodzaju alter ego osoby, skrucha Dawida nabiera dodatkowego znaczenia. Akt taki mógł być uznany za dużą szkodę, próbę przejęcia władzy nad osobą czy też otrzymania udziału w jej mocy ${ }^{89}$.

Żydowscy rabini wskazują na odniesienia do noszenia ozdobnego brzegu płaszcza z przepisowymi frędzlami w kilku innych miejscach ST. Dotyczy to na przykład Dn 3, 21 - wers opisuje wrzucenie Daniela i jego towarzyszy do rozpalonego pieca w ,ich płaszczach, obuwiu, tiarach i ubraniach”. Zostali oni cudownie uratowani, gdyż jak sugerują żydowskie źródła, zanosili błagalną modlitwę do Boga ubrani w płaszcze ozdobione nakazanymi przez Torę frędzlami ${ }^{90}$. $Z$ analogicznym argumentem wysłuchania modlitwy ze względu na przepisowy ubiór z frędzlami spotykamy się w odniesieniu do Iz 24, 16: „od krańca ziemi słyszeliśmy pienie”. Użyte tu słowo „kraniec” (פכָכְָָ) jest tym samym, które występuje w nakazie umieszczenia frędzli na „rogach" płaszcza. Interpretacja rabbiego Eliezera łączy te wyrażenia i sugeruje, że Bóg wysłuchuje modlitw Izajasza ze względu na przepisowy strój proroka ${ }^{91}$.

\section{WNIOSKI}

Istotnym wynikiem niniejszej pracy jest odrzucenie rozpowszechnionego poglądu, jakoby niewiasta cierpiąca na krwotok chwyciła się frędzli płaszcza Jezusa, ponieważ była to najdalsza część Jego szaty i przez ich dotknięcie najmniej narażała się na odkrycie swojego działania. Jakkolwiek nie było zwyczajem dotykanie obcej osoby (zwłaszcza innej płci), to jednak chora nie była wykluczona ze społeczności i nie musiała obawiać się ukarania za swój czyn. Sam jej dotyk nie sprowadzał stanu nieczystości na drugą osobę.

Równie bezpodstawne jest uznanie frędzli za najmniej znaczący element stroju i tłumaczenie działania kobiety jej wyjątkową wiarą w to, że dotknięcie nawet tak nieistotnej części szaty Jezusa może jej pomóc. Strój, a szczególnie płaszcz, był w starożytności ważnym znakiem informującym o pozycji właściciela. Jak zauważyliśmy, poza Izraelem szaty z przymocowanymi frędzlami nosili władcy, bogowie i żołnierze, zatem osoby o specjalnej randze. Natomiast w Izraelu wszyscy mężczyźni byli zobowiązani do noszenia frędzli. Stanowili oni szczególną własność Boga, Jego

89 Znane jest inne wyttumaczenie podawane przez rabinów. Dawid pozbawił Saula możliwości wypełniania przykazania noszenia frędzli i stąd jego serce tak mocno wypominało mu ten czyn. Por. R.E. Murphy, Odpowiedzi na 101 pytań o Torę, Kraków 2003, s. 51-52; F. STephens, The Ancient Significance of Sîșith s. 70 .

90 Por. B.Z. Bokser, The Thread of Blue, s. 14.

91 Por. tamże. 
wybrany naród, a to nadawało im specjalny status pośród innych ludów ${ }^{92}$. Widocznym świadectwem tego wyróżnienia były właśnie frędzle, których znaczenie nie było obce ościennym narodom.

Utożsamianie frędzli płaszcza z marginalnym, nieistotnym elementem ubioru często prowadziło do dopatrywania się w działaniu chorej kobiety nadzwyczajnej wiary i pokory zadowalającej się tym, co mało ważne (analogicznie do Syrofenicjanki, której wystarczyły „okruszyny spadające ze stołu panów” - por. Mk 7, 24-30; Mt 15,21-28). Nie jest możliwe poznanie poglądu bohaterki perykopy na znaczenie frędzli. Ewangeliści o tym nie piszą, jednak z przeprowadzonej analizy wynika, że kobieta sięgnęła po tę część szaty Jezusa celowo, spodziewając się, że dotknięcie owej ozdoby udzieli jej uzdrawiającej mocy. Potwierdzeniem tej tezy może być także inny fragment Ewangelii - nie tylko kobieta cierpiąca na krwotok, ale i chorzy z Mt 14, 36 próbują uchwycić się właśnie frędzli Jego płaszcza.

$\mathrm{Na}$ podstawie dokonanej analizy można sugerować, że niewiasta dotknęła frędzli płaszcza Jezusa z trzech powodów. Po pierwsze, dlatego że wiedziała, że cicit mają wyjątkowe religijne znaczenie w Izraelu; po drugie, z powodu przekonania, że ta część szaty może przekazywać moc i błogosławieństwo jej właściciela; po trzecie, z powodu wiary w szczególną moc tego konkretnego mężczyzny, w którym widziała kogoś więcej niż po prostu pobożnego Izraelitę - Mistrz z Nazaretu mógł być dla niej manifestacją boskości. Redaktorzy paralelnych tekstów, ukazując wszechwiedzę Jezusa (wie On, że frędzle Jego płaszcza zostały intencjonalnie dotknięte) i Jego nadzwyczajną moc, zdają się wskazywać na ten ostatni motyw działania kobiety. Dotknięcie frędzli jest wyrazem wiary w Boga, jaką ma chora, ale może być także wyrazem wiary w Boga, którego reprezentuje Jezus.

Przypuszczalnie zwyczaj noszenia cicit przez Izraelitów nie został przejęty ani od Babilończyków, ani od Sumerów, ani z Egiptu. Frędzle u płaszczy były tak szeroko rozpowszechnione na całym starożytnym Wschodzie, że bardziej prawdopodobne jest, iż to semiccy przodkowie Izraela przekazali sąsiadom ten zwyczaj wraz z jego symboliką, która przez wieki nabierała religijnego znaczenia ${ }^{93}$.

Wskazane starotestamentowe teksty odnoszące się do tej ozdoby łączą religijny sens frędzli z ich rozpowszechnionym znaczeniem ukazującym wysoki status danej osoby. Wydaje się, że zarówno magiczne myślenie pogańskie, jak i odniesienie do wszechmocy Boga Jahwe składało się na poglądy Żydów czasów Jezusa odnośnie do tej ozdoby.

92 Por. S. Bertman, Tasseled Garments in the Ancient East Mediterranean, s. 128.

93 Por. F.J. STEPHens, The Ancient Significance of Șisisith, s. 70. 


\section{WYBRANA BIBLIOGRAFIA}

BaERT B., Touching the Hem: The Thread between Garment and Blood in the Story of the Woman with the Haemorrhage (Mark 5:24b-34parr), „Textile: The Journal of Cloth and Culture" 9 (2011), s. 308-351.

Batten A.J., Clothing and adornment, „Biblical Theology Bulletin” 40/3 (2010), s. 148-159.

Bertman S., Tasseled Garments in the Ancient East Mediterranean, „The Biblical Archaeologist" 24/4 (1961), s. 119-128.

Bokser B.Z., The Thread of Blue, „Proceedings of the American Academy for Jewish Research" 31 (1963), s. 1-32.

Glover A.K., Modern Jewish Customs as Possible Helps in Bible Study, „The Biblical World" 18/1 (1901), s. 7-12.

GLOver A.K., The Dress of the Master, „The Biblical World” 15/5 (1900), s. 347-357. Goonnick B., The Tassel and the Blue Cord, „Jewish Bible Quarterly" 21/2 (1993), s. $99-108$.

Kubiś A., Kobieta cierpiąca na krwotok oraz córka Jaira jako symbol Izraela. Próba analizy symbolicznej Mk 5, 21-43, w: Studia nad Ewangelia wedtug św. Marka. Nowy Testament: geneza - interpretacja - aktualizacja (Lingua Sacra. Monografie 8), red. W. Linke, J. Kręcidło, Warszawa-Ząbki 2017, s. 66-111.

Milgrom J., Of Hems and Tassels, „Biblical Archaeology Review” 9/3 (1983), s. 61-65.

MiLler S., Women in Mark's Gospel, London-New York 2004.

StEPHEns F.J., The Ancient Significance of Sịșith, ,Journal of Biblical Literature” 50/2 (1931), s. 59-70.

StrZatKowsKa B., Rozporzadzenia dotyczqce kobiet w Kpt 15 (Rozprawy i studia biblijne 20), Warszawa 2006.

Tora Pardes Lauder. Bemidbar, red. i tłum. S. Pecaric, Kraków 2005.

VRIEs S.P.D. De, Obrzędy i symbole Żydów, tłum. A. Borowski, Kraków 2001. 


\section{ABSTRACT \\ AgnieszKa Ziemińska, CHR \\ "She Touched the Fringe of His Garment" (Luke 8:44). \\ The Interpretation of the Clause in the Light \\ of Ancient Biblical and Non-biblical Witnesses}

Touching Jesus' garment by a woman suffering from a twelve-year discharge of

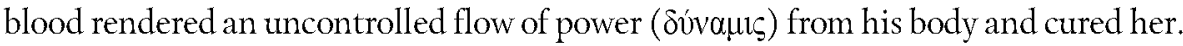
Did the fact that the woman's touch concerned this specific part of the robe of the Master of Nazareth have some meaning? Bearing in mind the law of wearing tassels upon the hem of the garment (Deut 22:12) as well as the prophecy from Zach 8:23, we follow the history and the meaning of this appendage to the garment. It is certain that tassels upon robes were not an idea that originated in Jewish culture. We find evidence of garments with this kind of adornment on two Minoan seal stones from around the $17^{\text {th }} \mathrm{c}$. BC, Assyrian bas-reliefs ( $9^{\text {th }} \mathrm{c}$. BC) and also on some Egyptian artefacts (starting from around $15^{\text {th }} \mathrm{c}, \mathrm{BC}$ ). They are visible as additions to the robes of both important people (king, priest) and deities. In many cultures, tassels upon the robe gave a special status to the person who wore them. They served as seals and as such they constituted an alter ego of a person. Touching or grasping the fringes of someone's robe gave the owner an affection and gave him that person's power.

It seems that the Jews, to the pre-existing custom of wearing this ornament, added, following God's command, a specifically Jewish order to put in the tassels a blue thread (Num 15:38). Wearing the fringes widened with a new dimension - they were supposed to remind people of God's commandments and his presence. In the case of the sick woman touching Jesus and also in the passage of Matt 14:34-36, where the sick people ask whether they could touch "the fringes of his cloak" both dimensions (ethnic - power, and specifically Jewish - memory of God commandments) are significant.

Keywords: Jewish fringes, tzitzit, denotation of attire, woman with a discharge of blood, Haemorrhoissa, ritual impurity, touching the fringe of a cloak

Słowa klucze: żydowskie frędzle, cicit, znaczenie stroju, kobieta cierpiąca na krwotok, haemorrhoissa, nieczystość rytualna, dotknięcie frędzli płaszcza 